\title{
LETTER
}

\section{The predictive role of early activation of natural killer cells in septic shock}

\author{
Raúl de Pablo*1,2, Jorge Monserrat ${ }^{\dagger 2}$, Carolina Torrijos², Mercedes Martín², Alfredo Prieto² and Melchor Alvarez-Mon \\ See related research by Andaluz-Ojeda et al., http://ccforum.com/content/15/5/R243, and related research by Monserrat et al., \\ http://ccforum.com/content/13/1/R26
}

\begin{abstract}
Recently, several studies about the role of natural killer (NK) cells in sepsis have been highlighted. In an earlier study, we characterized the abnormalities of circulating lymphocytes in 52 patients with septic shock during the first 28 days in the intensive care unit. Our results confirm and expand some previous reports. We found that patients who did not survive exhibited less NK cell $\left(\mathrm{CD}^{-}{ }^{-} \mathrm{CD} 56^{+}\right)$depletion than survivors and that these NK cells expressed CD69 ${ }^{+}$and $\mathrm{CD} 7^{+}$. These data demonstrate that NK cells are key participants in septic shock because patients who survived have more depletion and expressed less early activation and differentiation.
\end{abstract}

In a study that was published in a recent issue of Critical Care and that was conducted in a cohort of 50 patients with severe sepsis at intensive care unit (ICU) admission, Andaluz-Ojeda and colleagues [1] reported that absolute counts and relative concentrations of natural killer (NK) cells were significantly higher in patients who died.

In an earlier study, also published in Critical Care, we characterized the abnormalities of lymphocytes in 52 patients with septic shock during the first 28 days in the ICU [2]. Thirty-six healthy subjects served as controls. The study design was approved by the university hospital ethics committee, and all participants or their next of kin provided written informed consent.

Table 1 shows the significant differences found in the counts and percentages of lymphocyte subpopulations during the first week of follow-up. Like previous investigators,

${ }^{\dagger}$ Joint first authors

*Correspondence: raul.depablo@uah.es

'Intensive Care Unit, Hospital Universitario Príncipe de Asturias, Carretera de Alcalá-

Meco, SN. 28805, Alcalá de Henares, Madrid, Spain

Full list of author information is available at the end of the article we have found a reduced count of circulating NK cells in patients with septic shock, independently of their outcome [1,3]. Although patients who did not survive exhibited less NK cell depletion than survivors at ICU admission, there were no differences in $\mathrm{CD}^{\circ} 6^{+} \mathrm{CD}^{-}$cell counts in blood between survivors and non-survivors. These data are slightly in agreement with those reported by Andaluz-Ojeda and colleagues [1], who found that patients with the highest NK cell number had the lowest probability to survive. However, unlike GiamarellosBourboulis and colleagues [4], we did not find higher percentages of NK cells in patients who did not survive.

Using CD69 and CD57 surface antigens, we determined the counts and distributions of the activation stage of NK cells $\left(\mathrm{CD}^{-} \mathrm{CD}^{-} 6^{+}\right)$by flow cytometry. We obtained a significant increase in the counts and percentages of the $\mathrm{CD}^{-}{ }^{-} \mathrm{CD} 56^{+} \mathrm{CD} 69^{+}$cells in non-survivors at ICU admission and on day 3 (Figure 1). The mean fluorescence intensity for $\mathrm{CD} 6^{+} \mathrm{CD}^{-} \mathrm{CD}^{-} 9^{+}$cells was also significantly higher in non-survival patients than in survivors or controls $(30.6 \pm 4.2$ versus $20.3 \pm 2.6$ and $18.3 \pm 0.9$, respectively; $P<0.05$ for both). CD69 is rapidly induced in NK cells after activation and its role in NK cytotoxicity has been demonstrated in humans [5].

We further found a significantly higher percentage of $\mathrm{CD}^{-}{ }^{-} \mathrm{CD} 56^{+} \mathrm{CD} 57^{+} \mathrm{NK}$ cells in non-survival patients than in survivors and controls at ICU admission $(70.8 \% \pm 3.3 \%$ versus $57.3 \% \pm 9.2 \%$ and $53.6 \% \pm 3.7 \%$, respectively; $P<0.05)$. Non-survivors had a strong but not significant trend toward an increase of $\mathrm{CD}^{-} \mathrm{CD} 56^{+} \mathrm{CD} 57^{+} \mathrm{NK}$ cell count $(94.8 \pm 7.3$ versus $56.9 \pm 12.4$ cells per cubic millimeter). The expression of CD57, a long-lived marker and highly differentiated effector of NK cells, is increased in septic shock patients who died.

These data demonstrate an important role of NK cells as key participants in the early inflammatory response during septic shock. Patients who did not survive exhibited less NK cell depletion than survivors and these cells were very early activated and rapidly differentiated. We propose to asses NK cell phenotype and functions for 
Table 1. Counts and percentages of lymphocytes and their main subpopulations during the first week of follow-up in patients with septic shock and in healthy controls

\begin{tabular}{|c|c|c|c|c|c|c|c|c|}
\hline & & \multirow[b]{2}{*}{ Healthy controls } & \multicolumn{2}{|c|}{ At ICU admission } & \multicolumn{2}{|c|}{ After 48 hours } & \multicolumn{2}{|c|}{ On 7th day } \\
\hline & & & Non-survivors & Survivors & Non-survivors & Survivors & Non-survivors & Survivors \\
\hline \multirow[t]{2}{*}{ Lymphocytes } & Count & $2,095.9 \pm 67.0$ & $1,235.3 \pm 178.9^{a}$ & $1,048.4 \pm 192.0^{a}$ & $1,235.3 \pm 178.9^{a}$ & $1,048.4 \pm 192.0^{a}$ & $863.3 \pm 36.6^{a}$ & $886.2 \pm 178.9^{\mathrm{a}}$ \\
\hline & Percentage & $30.4 \pm 2.0$ & $7.0 \pm 1.7^{a}$ & $4.6 \pm 0.7^{a}$ & $9.5 \pm 0.4^{a, b}$ & $5.0 \pm 1.1^{\mathrm{a}}$ & $4.4 \pm 0.9^{\mathrm{a}}$ & $5.8 \pm 0.9^{a}$ \\
\hline \multirow[t]{2}{*}{$\mathrm{CD}^{+}$} & Count & $1,393.6 \pm 36.1$ & $745.9 \pm 145.7^{\mathrm{a}}$ & $740.0 \pm 151.8$ & $800.1 \pm 10.2^{\mathrm{a}}$ & $558.9 \pm 170.1^{\mathrm{a}}$ & $712.8 \pm 69.7^{a}$ & $574.9 \pm 147.6^{a}$ \\
\hline & Percentage & $71.4 \pm 1.7$ & $59.9 \pm 6.1$ & $65.9 \pm 4.2$ & $70.0 \pm 0.8$ & $56.7 \pm 8.9$ & $73.1 \pm 5.9$ & $63.8 \pm 4.6$ \\
\hline \multirow[t]{2}{*}{ CD19+ } & Count & $238.5 \pm 13.2$ & $259.8 \pm 83.8$ & $162.8 \pm 36.3$ & $170.2 \pm 4.0$ & $199.3 \pm 64.2$ & $131.7 \pm 83.9$ & $112.2 \pm 23.4^{\mathrm{a}}$ \\
\hline & Percentage & $10.7 \pm 0.9$ & $21.8 \pm 6.9$ & $15.9 \pm 3.0$ & $16.2 \pm 0.63^{\mathrm{a}}$ & $18.7 \pm 2.2^{\mathrm{a}}$ & $14.2 \pm 9.5$ & $14.3 \pm 2.3$ \\
\hline \multirow[t]{2}{*}{$\mathrm{CD}_{56}{ }^{+} \mathrm{CD}^{-}$} & Count & $356.8 \pm 28.4$ & $191.8 \pm 46.8^{\mathrm{a}}$ & $127.7 \pm 30.3^{\mathrm{a}}$ & $125.3 \pm 4.0^{\mathrm{a}}$ & $120.1 \pm 53.3^{\mathrm{a}}$ & $83.8 \pm 47.0^{\mathrm{a}}$ & $116.6 \pm 36.6^{\mathrm{a}}$ \\
\hline & Percentage & $16.8 \pm 1.9$ & $16.1 \pm 3.3$ & $18.6 \pm 2.9$ & $14.0 \pm 0.82$ & $12.5 \pm 3.7$ & $7.9 \pm 3.9$ & $13.2 \pm 2.2$ \\
\hline
\end{tabular}

All values are expressed as mean \pm standard deviation. 'Count' values are presented as cells per cubic millimeter, and 'Percentage' values are presented as percentages. The Mann-Whitney $U$ test for non-parametric data was used to analyze differences between the groups. ${ }^{P}<0.05$ between septic shock patients and healthy controls. ${ }^{b} P<0.05$ between survival and non-survival patients with septic shock. ICU, intensive care unit.
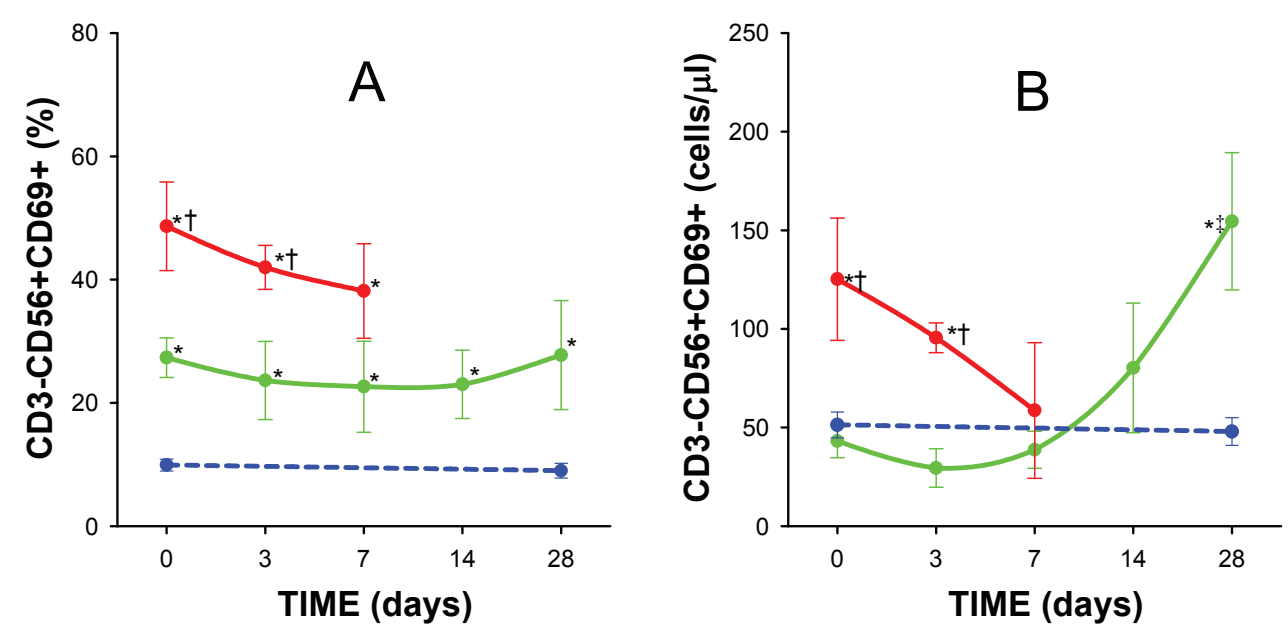

Figure 1. Kinetics of circulating blood percentage of total natural killer (NK) cells (A) and counts (B) of $\mathrm{CD}^{-} \mathrm{CD} 56^{+} \mathrm{CD} 69^{+} \mathrm{NK}^{-}$subset in patients with septic shock during their stay in the intensive care unit. Values are expressed as the mean percentage \pm standard deviation (A) or as the mean of cells per microliter \pm standard deviation (B). Data from non-survival patients, survivors, and healthy control subjects are shown in red, green, and blue, respectively. The Mann-Whitney $U$ test for non-parametric data was used to analyze differences between the groups, and analysis of variance followed by Wilcoxon signed-rank tests were used for within-group analyses. ${ }^{*} P<0.05$ for survivors or non-survivors versus controls; ${ }^{\dagger} P<0.05$ for survivors versus non-survivors; ${ }^{\ddagger} P<0.05$ for each follow-up time versus intensive care unit admission.

a better understanding of the physiopathology of sepsis in order to apply new therapies at an early stage.

\section{Abbreviations}

ICU, intensive care unit; NK, natural killer.

\section{Competing interests}

The authors declare that they have no competing interests.

\section{Author details}

IIntensive Care Unit, Hospital Universitario Príncipe de Asturias, Carretera Alcalá-Meco, SN. 28805, Alcalá de Henares, Madrid, Spain. '2Laboratory of Immune System Diseases and Oncology, National Biotechnology Center (CNB-CSIC) Associated Unit, Department of Medicine, Campus Universitario, Carretera Madrid-Barcelona, km 33,600, 28871, Alcalá de Henares, Madrid Spain. ${ }^{3}$ mmmune System Diseases and Oncology Service, Hospital Universitario Príncipe de Asturias, Carretera Alcalá-Meco, SN. 28805, Alcalá de Henares, Madrid, Spain.
Published: 7 March 2012

\section{References}

1. Andaluz-Ojeda D, Iglesias V, Bobillo F, Almansa R, Rico L, Gandía F, Loma AM, Nieto C, Diego R, Ramos E, Nocito M, Resino S, Eiros JM, Tamayo E, de Lejarazu $\mathrm{RO}$, Bermejo-Martin JF: Early natural killer cell counts in blood predict mortality in severe sepsis. Crit Care 2011, 15:R243.

2. Monserrat J, de Pablo R, Reyes E, Díaz D, Barcenilla H, Zapata MR, De la Hera A, Prieto A, Alvarez-Mon M: Clinical relevance of the severe abnormalities of the T cell compartment in septic shock patients. Crit Care 2009, 13:R26.

3. Venet F, Davin F, Guignant C, Larue A, Cazalis MA, Darbon R, Allombert C, Mougin B, Malcus C, Poitevin-Later F, Lepape A, Monneret G: Early assessment of leukocyte alterations at diagnosis of septic shock. Shock 2010, 34:358-363.

4. Giamarellos-Bourboulis EJ, Tsaganos T, Spyridaki E, Mouktaroudi M, Plachouras D, Vaki I, Karagianni V, Antonopoulou A, Veloni V, Giamarellou H: Early changes of CD4-positive lymphocytes and NK cells in patients with severe Gram-negative sepsis. Crit Care 2006, 10:R166. 
de Pablo et al. Critical Care 2012, 16:413

Page 3 of 3

http://ccforum.com/content/16/2/413

5. Borrego F, Robertson MJ, Ritz J, Pena J, Solana R: CD69 is a stimulatory receptor for natural killer cell and its cytotoxic effect is blocked by CD94 inhibitory receptor. Immunology 1999, 97:159-165. doi:10.1186/cc11204

Cite this article as: de Pablo $R$, et al:: The predictive role of early activation

of natural killer cells in septic shock. Critical Care 2012, 16:413. 